\title{
Formulation of Problem-Solving Design for Indonesian Informal Sector Migrant Workers Towards Post-Placement Independence: Case Study in Malaysia
}

\author{
Waridin Waridin ${ }^{1}$, Bambang Munas Dwiyanto ${ }^{1}$, Retno Saraswati ${ }^{2} \&$ Izza Mafruhah $^{3}$ \\ ${ }^{1}$ Faculty of Economics and Business, Diponegoro University, Semarang, Indonesia \\ ${ }^{2}$ Faculty of Law, Diponegoro University, Semarang, Indonesia \\ ${ }^{3}$ Faculty of Economics and Business, Universitas Sebelas Maret, Surakarta, Indonesia \\ Correspondence: Izza Mafruhah, Faculty of Economics and Business, Universitas Sebelas Maret, Surakarta, \\ Indonesia.
}

Received: December 4, 2019

Accepted: January 15, 2020

Online Published: March 5, 2020

doi:10.5430/rwe.v11n1p115

URL: https://doi.org/10.5430/rwe.v11n1p115

\begin{abstract}
The large number of Indonesian migrant workers can cause many problems. This study has purposes to identify placement and migrant workers problems, to identify the placement path and the common thread of migrant workers' problems, and to formulate a model of empowering post-placement migrant workers from Malaysia. The research method used in this study is mixed method, which is a combination of quantitative and qualitative variables. To answer the objectives use descriptive statistics are combined with Atlas, Analytical Hierarchy Process and qualitative analysis with indepth interview and Focus Group Discussion. The results show that the problems of migrant workers are divided into individuals and employers while the solution of the problem is prioritized by resolving the problems of migrant workers, completing during post-placement and training while in the shelter
\end{abstract}

Keywords: migrant worker, informal sector, Malaysia, empowerment

\section{Introduction}

The total population of Indonesia in 2018 is 265 million, resulting in a high workforce of 131.01 million in August 2018. Of these, 124.01 million people are employed, which resulted in open unemployment of around 5.3\%. Research conducted by the National Development Planning Agency (Bappenas) in 2014 found that 1\% economic development would open 400,000 jobs, and with an average development rate of 5\%, the number of unemployed could be reduced by around 2 million every year. However, this decline is not enough to overcome the growing unemployment. Therefore, working abroad is one of the main alternatives (Central Bureau of Statistics, 2018). The International Monetary Fund (IMF) states that Indonesia is the country with the tenth largest number of migrant workers in the world, with major destinations including Saudi Arabia, Malaysia, Taiwan and Hong Kong. The reasons for choosing these destination countries include religion, distance, language, income and culture. Placement of migrant workers abroad involves several parties, including National Body for the Placement and Protection of Indonesian Migrant Workers (BNP2TKI), Agency for the Service, Placement and Protection of Indonesian Migrant Workers (BP3TKI), Private Agency for the Placement of Indonesian Migrant Workers (PPTKIS), regional government through the office of manpower, migrant workers as actors, and community (Mafruhah et al., 2017).

The majority of labor migrants abroad have been driven by business motives and therefore economic principles have always been the main goal for PPTKIS when sending migrant workers so that psychological, cultural and sociological aspects are rarely considered. This condition triggers many problems for migrant workers starting from departure preparation, while working abroad, and after returning (Nuraeny, 2015). These problems can be divided into three main interconnected points: pre-placement, placement, post-placement. Research by Mafruhah et al. (2012) shows that placement has the most complex problems and requires serious handling. Data from BNP2TKI states that overall, from 2011 to 2016 there were 28,067 complaints of problems, which means that the annual average of is 4,678. The highest number of cases is in Saudi Arabia, with an average of 1,843 cases per year, while Malaysia becomes the second highest country. The large number of cases that is increasing from year to year is one reason to gradually reduce the number of migrant workers by gradually returning them to Indonesia and reducing the number 
of new placements or departures. The hope that the workers return to Indonesia needs to be done in a structured, integrated and comprehensive manner, starting from policy formulation, supporting facilities preparation, to development and mentoring efforts for migrant workers and their families since the placement period.

Migrant workers involved in a case cannot immediately return, so the government needs to prepare shelter for them. As long as they are at the shelter, they do not have productive activities or gain increased capacity and competence. BNP2TKI states that being a migrant worker should only be a safety valve when employment opportunities are limited amid high unemployment rates. Therefore, the next step is to prepare migrant workers to become self-reliant or independent by the central and local governments. This study aims to identify placement and migrant workers problems in Malaysia, to identify the placement path and the common thread of migrant workers' problems in Malaysia, and to formulate a model of empowering post-placement migrant workers from Malaysia.

\section{Literature Review}

The employment contract length of migrant workers is between two and four years with opportunities for extension until they are no longer productive. This timeframe allows them to raise money and increase human capital. Research has shown that migrant workers returning to their countries of origin will be able to implement the skills acquired so that they become brain gain and increase the accumulation of human capital (Wahba, 2014). As they can make a change of mindset, they will increase human capital for their home country (Dustmann \& Görlach, 2015; Dustmann \& Frattini, 2014).

Migrant workers who return have more values because they have worked in more developed countries both in terms of technology and production processes so that they are able to play a role in overcoming the constraints of human capital. If new knowledge obtained abroad can be transferred and used productively in the country of origin (Dustmann et al., 2011). Increased capability and change in mindset require integrated development through internal factors and external stimulation. This pattern of change is referred to as social engineering, which is interpreted as a change in the social conditions of society that does not occur naturally but involves the interference of other parties or manipulations aimed at influencing changes (Granger, 2001).

The increased human capital and social engineering is carried out through entrepreneurship (Mosey \& Wright, 2007; Dakhli \& De Clercq, 2004). Ducker (1985) states that entrepreneurship is an activity that is consistently carried out to convert good ideas into profitable activities. Further research on entrepreneurship especially in the regional information system categorizes features into three dimensions of social capital: structural, relational and cognitive (see for instance, De Carolis \& Saparito, 2006; Nahapiet \& Ghoshal, 1998). Entrepreneurs are more generally categorized as institutions and entrepreneurship. A more modern understanding implies a shift in entrepreneurial behavior from the original top down to bottom up (Yoon et al., 2015). Human capital development for migrant workers during the placement period is closely related to the use of remittances. The results of the study by Carling (2005) show that there are three patterns of remittance utilization by migrant workers.

First, direct consumption, where all remittances will be spent by the family for consumption purposes. In this pattern, there are no remittances used for savings or productive purposes. Second, personal saving, where the family of migrant workers will save both the whole or part of the remittance in the form of personal savings, such as bank deposits or gold, so that when migrant workers return home, the savings can be used as future living expenses. Third, personal investment, where migrant families will invest part or all of their remittances in the form of personal productive investments such as rice fields, boarding houses, freight cars, and motorcycle taxis. When combined with potential resources and entrepreneurship, this pattern will encourage the development and improvement of the economy of migrant workers and their communities (Carling, 2005).

\section{Method}

This study has purposes to identify placement and migrant workers problems, to identify the placement path and the common thread of migrant workers' problems, and to formulate a model of empowering post-placement migrant workers from Malaysia. The study was conducted in Malaysia. The research method used in this study is mixed method, which is a combination of quantitative and qualitative variables. To answer the first objective, descriptive statistics are combined with Atlas. The second objective will be discussed using the Analytical Hierarchy Process. Meanwhile, the third objective will be discussed using qualitative analysis with indepth interview and Focus Group Discussion.

\section{Results}

Most migrant workers are a labor force with low competence, which is indicated by the low level of education so that they are unable to compete with other work forces. BNP2TKI data show that the available job opportunities are more 
in the informal sector with triple D risk: dangerous, dirty, difficult. In addition, migrant workers also receive relatively low income. In total, the amount of remittances sent to Indonesia is quite large, but when compared to the number of migrant workers, it can be seen that the average remittance per person is relatively low.

In Malaysia, problems involving migrant workers are relatively high and continue to increase from year to year as shown in Table 1.

Table 1. The number of migrant workers with problems

\begin{tabular}{crrr}
\hline \multicolumn{1}{c}{ Year } & Placement & \multicolumn{1}{c}{ Problem } & $\%$ \\
\hline 2011 & 134,266 & 387 & 0.29 \\
2012 & 134,088 & 613 & 0.46 \\
2013 & 150,248 & 723 & 0.48 \\
2014 & 127,812 & 886 & 0.69 \\
2015 & 97,621 & 1,994 & 2.04 \\
2016 & 87,616 & 1,535 & 1.75 \\
2017 & 81,702 & 1,625 & 1.99 \\
\hline Total & 731,651 & 4,146 & 0.57 \\
\hline
\end{tabular}

Source: Kuala Lumpur Labor Attaché, 2017

Table 1 shows that the highest problem occurred in 2015 with 1,994 cases, equivalent to $2.04 \%$. This amount is only for cases that occurred in Kuala Lumpur and handled by shelters at the Indonesian Embassy, while cases that might occur at other consulates have not been recorded. In detail, the types of problems are shown in Table 2.

Table 2. Percentage of migrant workers by types of problem

\begin{tabular}{llc}
\hline No & Category & Percentage \\
\hline 1 & Unpaid salary & $48.62 \%$ \\
2 & Trafficking & $10.34 \%$ \\
3 & Physical abuse & $7.41 \%$ \\
4 & Sexual abuse & $2.41 \%$ \\
5 & Domestic violence & $0.95 \%$ \\
6 & Sickness & $10.00 \%$ \\
7 & Others & $20.26 \%$ \\
\hline & Total & $100.00 \%$ \\
\hline
\end{tabular}

Source: Kuala Lumpur Labor Attaché, 2017

Migrant workers at the shelter have a variety of problems, but generally can be grouped into two main problems, that are personal problems and employer problems, as shown in Figure 1. 


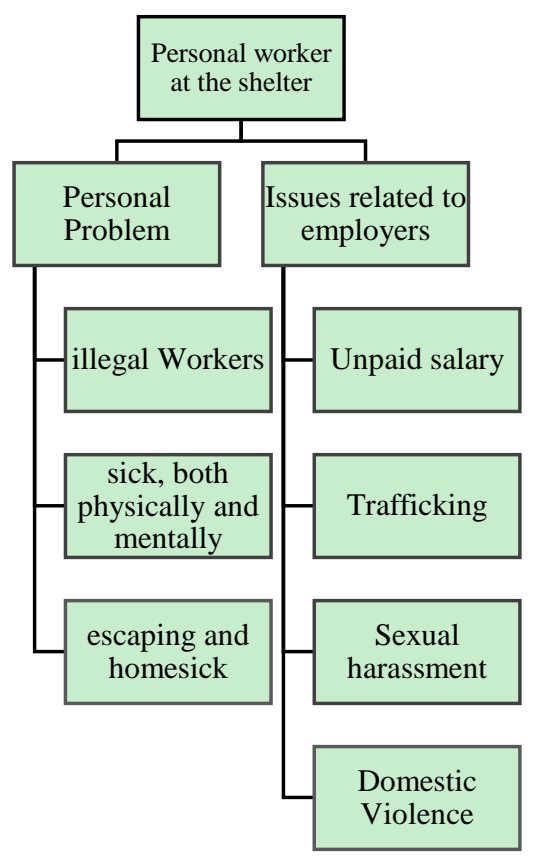

Figure 1. Problems with migrant workers at the shelters

The findings show that there are some personal problems experienced by migrant workers. First, illegal or without permit. The administration of work permits in Malaysia is relatively expensive, 3000 RM for two years and can be extended for 5 years by paying $2000 \mathrm{RM}$. The migrant workers also have to pay brokers to smoothen the permit issuance process. With an average salary of only 1,000 - 1,200 RM, most migrant workers choose to become illegal migrant workers. They will usually be protected by employers both in the domestic and informal sectors, although they are also often caught by raid officers. Second, sick, both physically and mentally. Data shows that the number of sick migrant workers reaches $10 \%$, which is dominated by workers in the household sector because of their very demanding jobs and limited rest periods. Diah, a migrant workersfrom Purbolinggo, East Java, stated that she had to clean a large house alone and do kitchen work. Lestari, a migrant worker from Brebes, stated that she resigned because she had to take care of five dogs alone. This unpredictable and dire work condition has caused migrant workers to suffer from physical and mental illness.

Third, escaping and homesick. This problem often occurs in migrant workers who have never worked abroad so they feel homesick and ask to be sent home. In such cases, migrant workers declare that they do not want to be a migrant worker again. In addition, migrant workers who already have some experience and usually work with good employers are complaining when they work with new but poor employers so they ask to be repatriated or choose to run away. In this case, they stated that they still wanted to become migrant workers but wanted to get new, better employers.

Meanwhile, there also issues related to employers or brokers. First, unpaid salary. This problem is caused by several reasons. The migrant workers have paid to the PPTKIS before placement and the employer has also paid to the PPTKIS or brokers to get the services of these migrant workers with the provision of salary deductions. This problem often occurs in migrant workers who work in the household sector because PPTKIS deceives them and then, employers simply refuse to pay migrant workers for various reasons. Second, trafficking, which reached $10.34 \%$. This condition needs serious handling from immigration parties, both in Malaysia and Indonesia. Trafficking will increase the number of illegal migrant workers. Third, sexual harassment. This case in Malaysia is relatively low compared to Saudi Arabia, but still requires serious attention so as not to worsen. Fourth, domestic violence, which is almost the same as sexual abuse. This case occurs because of poor communication between migrant workers and employers, and also because of the personality of the employers.

Because of these problems, the Indonesian Embassy through labor attaches needs to provide intensive assistance, especially in cases that cause mental disorders, with firstly identifying the needs of migrant workers. The problems of migrant workers can be solved by taking into account the needs tree processed with the Analytical Hierarchy Process 
(AHP), which identifies and structures problems based on priority needs. Identification of the problem produces the problems tree, as shown in Figure 2.

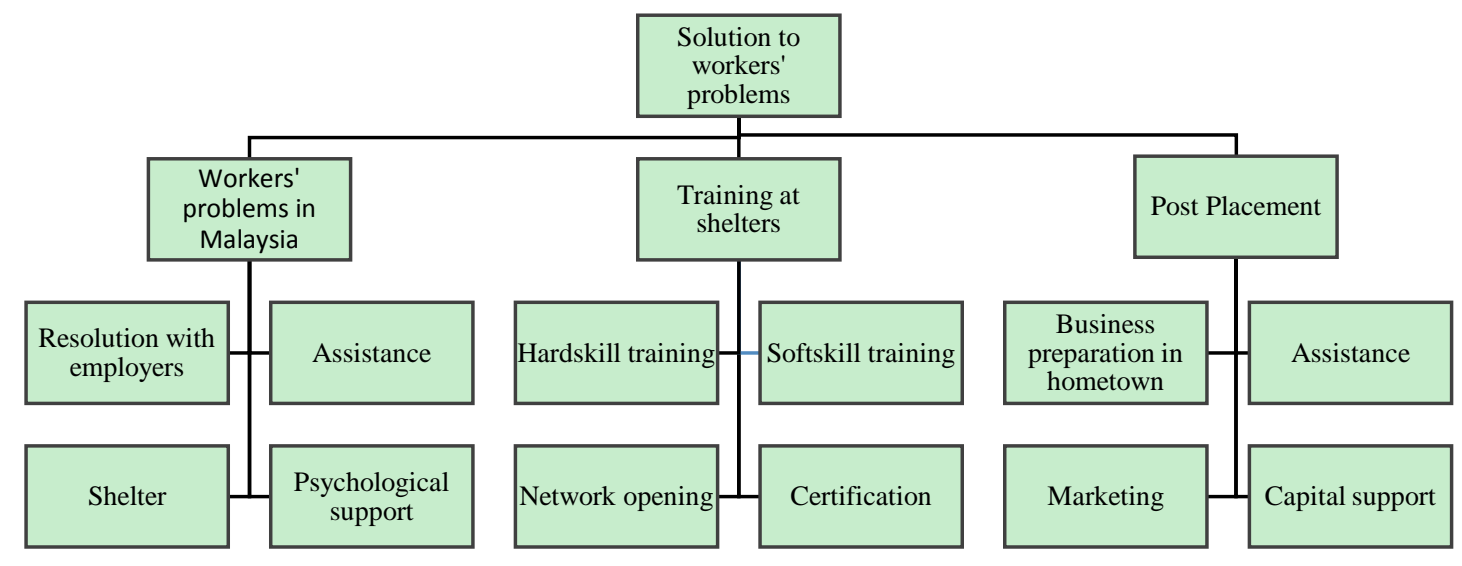

Figure 2. Identification of the problem

The sources used in this analysis consisted of 30 migrant workers placed at the shelter, 3 shelter managers, and 2 labor attaché staff. Data and information were obtained through in-depth interviews and then enumerated and processed with AHP with the following results. At level 1, the three main problems that attract key persons' attention are the settlement of migrant workers' cases, training in shelter, and post-placement (Table 3).

Table 3. Priority factors that influence the success of potential development at level 1

\begin{tabular}{lcc}
\hline Criteria & Priority Values & Rank \\
\hline Case settlements & 0.42 & 1 \\
Training in shelters & 0.24 & 3 \\
Post-placement & 0.32 & 2 \\
\hline
\end{tabular}

Table 3 shows that case resolution is the criteria with the highest priority value. Workers' problems usually cannot be clearly specified into either criminal or civil law, so the resolution creates a dilemma because of the absence of clear legal arrangements. Problems with violence, unpaid salaries, retained passports and other domestic problems take a long time to resolve because of conflicting interests. Even in some cases, workers do not expect much of their rights because the most important thing for them is how to obtain their passport back and then return home. The second priority is post-placement handling. Workers who are involved in problems in the destination country often experience trauma and do not want to become migrant workers anymore, but at the same time their economy and family must still be supported. Therefore, employment or business opportunities during post placement are the second priority. The third priority is shelter. Shelter is very helpful for migrant workers involved in problems in the destination country, but not all destination countries have adequate shelter. The shelter located in Kuala Lumpur is adequate because it has decent facilities such as rest rooms, kitchens, food, and halls as activity centers. Workers placed here experience time efficiency problems, even though the duration of stay depends on the type of case faced. The large number of workers and their heterogeneous backgrounds are also vulnerable to conflict. Therefore, training or other capacity building 
activities are an important part of resolving cases from migrant workers in Kuala Lumpur. This is in accordance with the findings of Mafruhah et al. (2016) which emphasizes the importance of focusing on improving labor welfare during the placement period.

Each criterion in level 1 will be derived to level 2, which explains or specifies criteria at level 1 . The case resolution criterion is derived into four criteria. The results of the AHP calculation are shown in Table 4.

Table 4. Factors that influence the case resolution at level 2

\begin{tabular}{lcc}
\hline Criteria & Priority Values & Rank \\
\hline Case resolution & 0.35 & 1 \\
Shelter & 0.15 & 4 \\
Assistance & 0.27 & 2 \\
Psychological support & 0.23 & 3 \\
\hline
\end{tabular}

Table 4 shows that case resolution is the first priority at level 2 because this activity needs to involve the embassy or consulate as a representative for Indonesian citizens abroad. The stronger the bargaining position of the Indonesian government, the faster the resolution of cases and the more appropriate the risks and benefits / losses faced by migrant workers both financially and non-financially. The second priority is assistance. Many cases require a long and complicated solution, so assistance is an important part. The next priority is psychological support. Workers involved in a problem will usually experience pressure from the problems they are facing or family pressure, so they need psychological help. The fourth priority is adequate shelter. Workers do not need luxurious and large facilities; they prefer facilities that can provide protection. This is in accordance with the findings of Chib et al. (2013) which states that psychological support through telephone network access is needed to increase social support among migrant workers in Singapore. Wong and Leung (2008) also found that social support and assistance can increase the resilience of migrant workers in China and affect their mental health.

At level 2, post-placement factors are influenced by four criteria. The results of AHP calculations are shown in Table 5.

Table 5. Priority on factors that influence post placement at level 2

\begin{tabular}{lcc}
\hline Criteria & Priority Values & Rank \\
\hline Business preparation at hometown & 0.27 & 2 \\
Assistance & 0.21 & 3 \\
Capital & 0.21 & 4 \\
Marketing & 0.31 & 1 \\
\hline
\end{tabular}

Table 5 shows that marketing is the first priority. Migrant workers expect that the government helps them in this matter because marketing is an important part of preparing new businesses because even though the business is very strong, its success is still influenced by the success in selling goods or services. The second priority is business preparation in the area of origin which is directly related to the ability, skills and willingness to own a business. The third priority is continuous assistance starting from improving product quality to management assistance. The fourth priority is capital. The need for capital is not the first choice because generally migrant workers have the courage to start a new business with minimum initial capital. Training at the shelter consists of four criteria as shown in table 6. This confirms Sayan's (2006) findings regarding the possibility of using remittances for doing business at home. For this reason, migrant workers tend to choose savings to secure their current income, for the purpose of doing business or entrepreneurship when they return home. 
Table 6. Priority on training at shelter

\begin{tabular}{lcc}
\hline Criteria & Priority Values & Rank \\
\hline Hard skill training & 0.19 & 4 \\
Soft skill training & 0.32 & 1 \\
Network opening & 0.28 & 2 \\
Certification & 0.21 & 3 \\
\hline
\end{tabular}

Table 6 shows that the types of training that are considered most important by key persons are soft skills training, such as achievement motivation training and business motivation training. Both training are expected to provide direction for migrant workers to start businesses in their home areas. The second priority is the opening of a network, where key people realize that the business will succeed when there is involvement from third parties. Therefore, networking with external parties will open up new opportunities for workers. The third priority is certification because this is considered as a form of recognition that migrant workers have certain skills. At present, various employment opportunities require certification in accordance with the required fields, such as beauty salon certificates and cooking certificates. The fourth priority is hard skill training which is currently considered not very important by migrant workers because these skills can be improved by themselves. All priorities at level 1 and level 2 indicate the efforts that must be made by stakeholders to solve migrant workers' problems at the shelter. This confirms the findings of Heyes (2009) who analyzed the education and training efforts for migrant workers to prepare a system for recruiting and organizing migrant workers. This also supports the findings of Ziguras and Law (2006) which state that workers with adequate skills and education are more likely to be chosen by employers in the Australian context.

\section{Conclusion}

This study aims to identify placement and migrant workers problems in Malaysia, to identify the placement path and the common thread of migrant workers' problems in Malaysia, and to formulate a model of empowering post-placement migrant workers from Malaysia. This is motivated by the fact that migrant workers involved in a case cannot immediately return, so the government needs to prepare shelter for them. As long as they are at the shelter, they do not have productive activities or gain increased capacity and competence. The results of this study indicate that the problems faced by migrant workers when they live in shelters can be grouped into two, that are personal problems and employer problems. Worker's priorities include case resolutions in the destination country, facilitation expectations in the area of origin after placement, and training at the shelter.

This finding is theoretically useful to explain the factors that have influenced the emergence of migrant worker problems in several recipient countries in Asia. In addition, these findings also contribute to explaining coherently the problems and the order of problems experienced by Indonesian migrant workers in Malaysia. Practically, this finding recommends to the government and labor bureaus to improve skills through workforce education and training, and increase employability and social support for migrant workers.

This study has a limitation where the analysis is not carried out with a causality model, so the effect between these factors with demand and quality of work is unknown. Future research is expected to use the factors in this study in the analysis of causality with the quality of work and the demand for migrant workers.

\section{Acknowledgments}

The authors would like to thank The National Board for The Placement and Protection of Indonesian Overseas Worker (BNP2TKI) and Indonesian Ministry of Manpower for valuable research support in Indonesia and Malaysia.

\section{References}

Carling, J. (2005). Migrant remittances and development cooperation. Oslo Norway: Prio.

Central Bureau of Statistics. (2018). Open unemployment according to the Highest Education Completed. Jakarta: Central Statistics Agency. Retrieved from https://www.bps.go.id/linkTabelStatis/view/id/972

Chib, A., Wilkin, H. A., \& Hua, S. R. M. (2013). International migrant workers' use of mobile phones to seek social support in Singapore. Information Technologies \& International Development, 9(4),1-19.

Dakhli, M., \& De Clercq, D. (2004). Human capital, social capital, and innovation: a multi-country study. Entrepreneurship \& regional development, 16(2), 107-128. 
De Carolis, D. M., \& Saparito, P. (2006). Social capital, cognition, and entrepreneurial opportunities: A theoretical framework. Entrepreneurship theory and practice, 30(1), 41-56.

Ducker, P. (1985). Innovation and entrepreneurship: Practice and principles. New York: Harper \& Row.

Dustmann, C., \& Frattini, T. (2014). The fiscal effects of immigration to the UK. The Economic Journal, 124(580), F593-F643.

Dustmann, C., \& Görlach, J.-S. (2015). Selective Out-Migration and the Estimation of Immigrants' Earnings Profiles. Handbook of the Economics of International Migration (Vol. 1).

Dustmann, C., Fadlon, I., \& Weiss, Y. (2011). Return migration, human capital accumulation and the brain drain. Journal of Development Economics, 95(1), 58-67.

Granger, S. (2001). Social engineering fundamentals, part I: hacker tactics. Security Focus, 18.

Heyes, J. (2009). Recruiting and organising migrant workers through education and training: A comparison of Community and the GMB. Industrial Relations Journal, 40(3), 182-197.

Mafruhah, I., Istiqomah, N., Mulyani, N. S., \& Rahardjo, M. (2016). The Placement Model for Indonesian Migrant Workers to Improve their Economic Welfare. Journal of Business and Economics Review (JBER), 1(1), 42-50.

Mafruhah, I., Sarsito, T., \& Gravitiani, E. (2012). The Welfare of the Indonesian Migrant Workers (TKI) in the Land of a Malay Nation: A Socio-Economic Analysis. Southeast Asian Journal of Social and Political Issues, 1(2), 246-271.

Mafruhah, I., Waridin, W., \& Dinar, D. (2017). Analyze The Social Economy Condition of Indonesian Migrant Workers, the Way to Improve the Welfare: A Case Study in Hongkong. International Journal of Economic Research, 14(8), 1-8.

Mosey, S., \& Wright, M. (2007). From human capital to social capital: A longitudinal study of technology-based academic entrepreneurs. Entrepreneurship Theory and Practice, 31(6), 909-935.

Nahapiet, J., \& Ghoshal, S. (1998). Social capital, intellectual capital, and the organizational advantage. Academy of Management Review, 23(2), 242-266.

Nuraeny, H. (2015). Pengiriman Tenaga Kerja Migran Sebagai Salah Satu Bentuk Perbudakan Modern dari Tindak Pidana Perdagangan Orang. Jurnal Hukum dan Peradilan, 4(3), 501-518.

Sayan, S. (2006). Business cycles and workers' remittances: How do migrant workers respond to cyclical movements of GDP at home? (No. 6-52). International Monetary Fund.

Wahba, J. (2014). Return migration and economic development. International handbook on migration and Economic Development, 327.

Wong, D. F. K., \& Leung, G. (2008). The functions of social support in the mental health of male and female migrant workers in China. Health \& Social Work, 33(4), 275-285.

Yoon, H., Yun, S., Lee, J., \& Phillips, F. (2015). Entrepreneurship in East Asian Regional Innovation Systems: Role of social capital. Technological Forecasting and Social Change, 100, 83-95.

Ziguras, C., \& Law, S. F. (2006). Recruiting international students as skilled migrants: the global 'skills race'as viewed from Australia and Malaysia. Globalisation, Societies and Education, 4(1), 59-76. 